\title{
Effect of dietary glutamine supplementation associated with threonine levels in the intestinal mucosa of broilers challenged with Eimeria sp. from 22 to 42 days of age
}

\author{
Efeito da suplementação de glutamina em dietas associadas com \\ níveis de treonina sobre a mucosa intestinal de frangos de corte \\ desafiados com Eimeria sp., de 22 a 42 dias de idade
}

\author{
Jovanir Inês Müller Fernandes ${ }^{1 *}$; Alice Eiko Murakami²; Anete Rorig; \\ Heloisa Lais Fialkowski Bordignon ${ }^{4}$; Mayra Vissotto Ribeiro3; \\ Isabelle Naemi Kaneko ${ }^{5}$; Tatiana Carlesso dos Santos ${ }^{2}$
}

\begin{abstract}
The aim of this study was to evaluate the effects of glutamine and threonine supplementation on the ileal mucosa of broilers aged 21-42 days. Six-hundred and forty-one-day old chicks of the Cobb Slow lineage were utilized in this study. From 1 to 21 days of age, the chicks received a commercial diet; and after 22 days, the broilers were distributed in a completely randomized design in a $2 \times 4$ factorial scheme (challenge and diet), with 4 replications and 20 chicks per experimental unit. At 22 days of age, the challenged broilers received a commercial vaccine against coccidiosis. A commercial diet was utilized as control and three other diets were formulated with reduced crude protein $(-3 \%)$, and were corrected with the addition of glutamine (Gln) and glutamic acid (Glu) as non-specific nitrogen sources, and finally supplemented with L-Threonine (Thr) at $0.70,0.80$, and $0.85 \%$ digestible threonine, respectively. At 28 days of age, diets with $\mathrm{Gln} / \mathrm{Glu}+\mathrm{Thr}$ resulted in greater ileal villi lengths. Challenge with Eimeria sp. reduced the number of goblet cells and increased the duodenal and jejunal crypt depths. At 42 days of age, an interaction was observed between diet and challenge in relation to ileal villi length; better results were observed in the challenged broilers that received $0.85 \% \mathrm{Gln} / \mathrm{Glu}+\mathrm{Thr}$. The mucosal morphology in the ileal villi extremities was preserved in the challenged broilers that received higher Thr levels in their diets. The results suggested that the inclusion of glutamine and threonine affected the morphometry and mucosa of the ileum, thereby improving the mucosal quality.
\end{abstract}

Key words: Amino acids. Cellular morphology. Ileal morphometry. Mucin.

1 Profa, Programa de Pós-Graduação em Ciência Animal, PPGCA, Universidade Federal do Paraná, UFPR, Palotina, PR, Brasil. E-mail: jimfernandes@ufpr.br

2 Profas, Programa de Pós-Graduação em Zootecnia, PPZ, Universidade Estadual de Maringá, UEM, Maringá, PR, Brasil. E-mail: aemurakami@uem.br; tcsantos@uem.br

3 Discentes, Curso de Mestrado, Programa de Pós-Graduação em Ciência Animal, PPGCA, UFPR, Palotina, PR, Brasil. E-mail: aneterorig@gmail.com; mavissotto@hotmail.com

4 Discente, Curso de Graduação em Medicina Veterinária, UFPR, Palotina, PR, Brasil. E-mail: heloisa.veterinaria@gmail.com

5 Discente, Curso de Doutorado, Programa de Pós-Graduação em Zootecnia, PPZ, UEM, Maringá, PR, Brasil. E-mail: isabellenaemi@hotmail.com.

* Author for correspondence 


\section{Resumo}

O objetivo deste estudo foi avaliar os efeitos da suplementação de glutamina e treonina sobre a mucosa ileal de frangos de corte de 21 a 42 dias de idade. Foram utilizados 640 pintos da linhagem Cobb Slow. De 1 a 21 dias de idade, as aves receberam dieta comercial, e a partir de 22 dias foram distribuídas em um delineamento completamente casualizado seguindo um esquema fatorial $2 \times 4$ (desafio e dieta), com 4 repetições e 20 aves por unidade experimental. As aves foram desafiadas através da vacina de coccidiose. A dieta comercial foi utilizada como controle, e três outras dietas foram formuladas com proteína bruta reduzida (-3\%) e corrigidas com a adição de glutamina e ácido glutâmico como fontes de nitrogênio não especificas, e então suplementadas com L-treonina, totalizando $0.70,0.80$ e $0.85 \%$ de treonina digestível, respectivamente. Aos 28 dias de idade, dietas com Gln/Glu+Thr mostraram maiores comprimentos de vilo na região do íleo, e o desafio com Eimeria sp reduziu o número de células caliciformes e aumentou a profundidade das criptas do duodeno e do íleo. Aos 42 dias de idade, houve uma interação entre dieta e desafio com relação ao comprimento do vilo do íleo, apresentando melhores resultados em aves desafiadas que receberam a dieta com $0.85 \% \mathrm{Gln} / \mathrm{Glu}+\mathrm{Thr}$. A morfologia da mucosa em região de extremidades de vilos no íleo foi preservada em aves desafiadas que receberam o maior nível de treonina na dieta. Os resultados sugerem que a inclusão de níveis de glutamina e treonina influenciaram a morfometria ileal, melhorando assim a qualidade da mucosa.

Palavras-chave: Aminoácidos. Morfologia celular. Morfometria ileal. Mucina.

\section{Introduction}

The gastrointestinal tract is not only recognized as an organ of digestion and absorption but also an organ with important immunological role because of its participation in the defense against external damage (GUARNER, 2006). The intestinal mucosa is exposed to a wide variety of antigens from feedstuffs, resident bacteria, and invader microorganisms, which need to be limited by the mucosal barrier that provide an immunological defense against harmful antigens (WITTIG; ZEITZ, 2003 ). Around $20 \%$ of the energy obtained from diet is directed to the maintenance of these functions that also expend $25 \%$ of the daily protein synthesized in the body. Additionally, the intestinal mucosa is responsible for utilizing 17 to $25 \%$ of the oxygen intake in the body. Therefore, it is an expensive metabolic organ that is severely affected when nutrient intake is decreased (KLASING, 2007).

The epithelial cell populations of the intestinal mucosa are modulated by a number of factors that are present within the lumen, epithelium, or the underlying lamina propria (DIGNASS, 2001; SAKAMOTO et al., 2014). Several distinct peptide families have been recognized to modulate different cellular functions of the intestinal cell populations, including cell migration, proliferation, and/or differentiation. The identification and characterization of numerous regulatory peptide and non-peptide factors have led to the recognition of a network of interrelated factors within the intestine. Glutamine (Gln) is a non-peptide factor that stimulates the proliferation and migration of intestinal epithelial cells (DIGNASS, 2001; RAO; SAMAK, 2012). Gln, which is the most abundant amino acid found in both the intracellular and extracellular compartments, is produced by the action of glutamine synthase and is required for a number of cellular functions. It is best known for its ability to serve as a source of energy for the cells such as enterocytes (RAO; SAMAK, 2012).

Metabolically, Gln is an important source of glucose required for the maintenance of cellular functions (RAO; SAMAK, 2012), particularly for the proper development and maintenance of the physiological balance of depressed animals or of those that are exposed to stress (TAPIERO et al., 2002). A significant evidence indicates that Gln preserves the gut barrier function and prevents permeability to toxins and pathogens under various 
conditions of gastrointestinal mucosal injury (FASINA et al., 2010). Gln also induces gene transcription for the activation of the ornithinedecarboxylase enzyme (ODC), which is essential for the cell proliferation process (LIN et al., 1998).

Threonine (Thr) is the third limiting amino acid of broilers, after methionine and cysteine, and lysine (KIDD et al., 1997). It has important roles in protein synthesis, which is essential for the maintenance of health and intestinal integrity (FAURE et al., 2005; STAR et al., 2012). Compared to other essential amino acids, Thr content represents more than $30 \%$ of the proteins of the intestine (NICHOLS; BERTOLO, 2008), thereby suggesting that Thr affects intestinal functionality and maintenance (MOGHADDAM et al., 2011; MYRIE et al., 2006; CORZO et al., 2007). It has been estimated that more than half of dietary Thr consumed is retained in the intestine to fulfill such gut-maintenance functions and is primarily used during mucin synthesis. Mucin glycoproteins consist of peptides enriched in Thr and have been estimated to comprise nearly a third of the proteins utilized in mucin (STAR et al., 2012).

Intestinal mucus is the non-immune defense mechanism (KIDD, 2004) and plays an important role in mucosal protection against physical abrasion owing to diet ingestion (LAW et al., 2007). During enteric disease, there is an increase in the mucin secretion by the digestive tract for the maintenance of a protective barrier (MONTAGNE et al., 2004). In addition, as mucus binds a large variety of bacteria, it stimulates the formation of the immune response mediated by secretory IgA, which not only prevents the invasion of intestinal bacteria in intestinal cells but also selectively facilitates the growth of the normal intestinal microflora (YEGANI; KORVER, 2008).

Because of the high amino acid requirements to meet the protein deposition, requirements in current broiler lineages, the capacity of endogenous synthesis and stored Gln cannot meet the enteric demand. As a result, supplementation of Thr can be inadequate to guarantee mucosal protection (CORZO et al., 2007). Kidd (2004) observed an increase from 2 to $10 \%$ in the Thr requirement of broilers raised in contaminated environments compared to clean environments. Such increased need of specific nutrients can have a large economic impact when the sanitary status of lots and installations are not considered in the creation of nutritional programs.

Rearing birds under intensive conditions upon litter provides an ideal opportunity for parasite transmission, particularly Eimeria that develop in the intestinal tract and have an oral/fecal life cycle. Thus, coccidiosis remains the most expensive and common enteric disease during poultry production. Its pathogenesis is characterized by damage that is caused by the reproductive cycle of parasites in the intestinal cells of the hosts (ABBAS et al., 2011). Due to their intracellular replication, Eimeria destroys cells, thereby resulting in functional losses because of the structural alteration and atrophy, which leads to mortality, interruption of digestive processes or nutrient absorption, reduced weight gain, and increased susceptibility to other disease agents. Subclinical coccidiosis can be an important contributing factor in the development of necrotic enteritis in broiler chickens because mucosal damage facilitates the establishment and multiplication of Clostridium perfringens (ABBAS et al., 2011; TAN et al., 2014).

Therefore, the aim of this study was to evaluate the effect of dietary glutamine supplementation associated with increasing levels of threonine on the mucosal integrity and morphometric measures of the duodenum, jejunum, and ileum of 22-42 dayold broilers, challenged and not challenged with Eimeria sp.

\section{Materials and Methods}

The study was performed in accordance with the standards of the Brazilian College of Animal Experimentation (COBEA); and the Animal 
Experimentation Ethics Committee of Federal University of Parana - Palotina approved all the procedures involved in the study (04/2012).

\section{Birds and experimental diets}

Six-hundred and forty male chicks of the Cobb Slow lineage of 22 days of age were randomly distributed into a completely randomized design in a $2 \times 4$ factorial scheme (challenge and diet), with 4 replicates and 20 animals in each scheme, totaling to 32 experimental floor pens. The poultry barn had a thermostatically controlled environment in order to keep the temperature at $25 \pm 2{ }^{\circ} \mathrm{C}$ and relative humidity at $61 \pm 10 \%$. The floor pens with $3.75 \mathrm{~m}^{2}$ had wood shavings on the floor and were equipped with one feeder and one drinker.

A maize/soybean meal-based commercial diet was utilized as a control and three other diets were formulated with a reduced crude protein $(-3 \%)$, and corrected with the addition of glutamine and glutamic acid $\left(\right.$ AminoGut $^{\mathbb{B}}$ ) as non-specific nitrogen sources. AminoGut is a commercial dietary supplement produced by Ajinomoto do Brazil (São Paulo, Brazil), and consists of a mixture of L-glutamine (minimum 10\%) and L-glutamate (minimum 10\%). Out of the three diets, one had the same Thr level $(0.70 \%)$ as that of control diet (whole protein). Increasing levels of supplementary Thr were obtained by adding L-Thr $(0,160$, and 210 $\mathrm{mg} / \mathrm{kg}$ ), which corresponded to 0.80 and $0.85 \%$ of digestible Thr levels. Diets were based on corn and soybean meal and were formulated according to the chemical composition of the feedstuffs and the nutritional recommendations that were adopted by poultry companies of the region (Table 1 ). The birds had free access to feed and water throughout the experimental period.

Table 1. Percentage composition and calculated nutrient levels of the experimental diets of broilers during the growth period /finisher (22-42 days).

\begin{tabular}{|c|c|c|c|c|}
\hline & & \multicolumn{3}{|c|}{ Treatments } \\
\hline Ingredients, $\%$ & Basal diet & Gln/Glu & Gln/Glu $+0.80 \% \mathrm{Thr}$ & $\mathrm{Gln} / \mathrm{Glu}+0.85 \% \mathrm{Thr}$ \\
\hline Yellow corn & 59.28 & 60.66 & 60.46 & 60.41 \\
\hline Soybean meal & 34.30 & 30.20 & 30.20 & 30.20 \\
\hline Soybean oil & 3.30 & 2.70 & 2.80 & 2.80 \\
\hline Salt & 0.39 & 0.39 & 0.39 & 0.39 \\
\hline Limestone & 1.010 & 1.020 & 1.020 & 1.020 \\
\hline Dicalcium Phosphate & 0.990 & 1.030 & 1.030 & 1.030 \\
\hline DL-Methionine $98 \%$ & 0.275 & 0.320 & 0.320 & 0.320 \\
\hline L-lysine $80 \%$ & 0.095 & 0.230 & 0.230 & 0.230 \\
\hline Vitamin and mineral premix $x^{1,2}$ & 0.300 & 0.300 & 0.300 & 0.300 \\
\hline AminoGut ${ }^{3}$ & - & 3.000 & 3.000 & 3.000 \\
\hline L-Threonine $98 \%$ & - & 0.065 & 0.160 & 0.210 \\
\hline \multicolumn{5}{|l|}{ Calculated levels } \\
\hline Crude protein, $\%$ & 21.12 & 21.15 & 21.21 & 21.24 \\
\hline EM Kcal/Kg & 3,150 & 3,150 & 3,150 & 3,150 \\
\hline Calcium, \% & 0.86 & 0.86 & 0.86 & 0.86 \\
\hline Available Phosphorus, \% & 0.43 & 0.43 & 0.43 & 0.43 \\
\hline
\end{tabular}


continuation

$\begin{array}{lllll}\text { Lysine Dig., \% } & 1.101 & 1.101 & 1.100 & 1.100 \\ \text { Methionine Dig., \% } & 0.558 & 0.580 & 0.579 & 0.579 \\ \text { Cystine Dig., \% } & 0.292 & 0.270 & 0.269 & 0.269 \\ \text { Methionine + Cystine Dig., \% } & 0.850 & 0.849 & 0.849 & 0.849 \\ \text { Threonine Dig., \% } & 0.707 & 0.707 & 0.799 & 0.848 \\ \mathrm{Na} \% & 0.179 & 0.180 & 0.180 & 0.180 \\ \mathrm{Cl} \% & 0.309 & 0.340 & 0.340 & 0.340 \\ \mathrm{~K} \% & 0.883 & 0.803 & 0.802 & 0.802\end{array}$

${ }^{1}$ Vitamin Blend (content per kg of premix): Vit. A 7.000.000,00 IU; Vit. D3 2.200.000,00 IU; Vit.E 11.000,00 mg; Vit. K3 1.600,00 mg; Vit. B1 2.000,00 mg; Vit. 5.000,00 mg B2, Vit. B12 12.000,00 mg; Niacin 35.000,00 mg; Pantothenic acid 13.000,00 mg; Folic acid 800,00 mg; Antioxidant 100,000.00; q.s. vehicle 1.000,00 g.

${ }^{2}$ MineralBlend (content per kg of premix): Iron 10.000,00 mg; Copper 16.000,00 mg; Iodine 2.400,00 mg; Zinc 100.000,00 mg; Manganese 140.000,00 mg; Selenium 400,00 mg; q.s. vehicle 1.000,00 g

${ }^{3}$ Source of Gln/Glu.

\section{Experimental challenge}

At 22 days of age, chickens of the coccidiosischallenged groups were orally treated twenty times with the labeled-recommended individual commercial dose (1000 doses per bottle of freeze dried vaccine) of coccidial vaccine that contained live and attenuated oocysts of Eimeria acervulina, E. maxima, E. praecox, E. tenella, and E. mitis. In a previous study by Tan et al. (2014), this dose induced moderate intestinal damage.

Prior to the application of the vaccine, sporulation of oocysts was performed by the injection of oxygen directly into Falcon tubes with the vaccine, which were quickly sealed and maintained in a refrigerated Biochemical Oxygen Demand (BOD) incubator at $28{ }^{\circ} \mathrm{C}$ for 48 hours. The challenged group of birds received $2.0 \mathrm{~mL}$ of the inoculum $( \pm 80,000$ oocysts) directly in the crop.

\section{Histomorphometric analysis}

At 28 and 42 days of age, two broilers per experimental unit were submitted to electrical stunning and then slaughtered by severing the jugular vein, immediately followed by bleeding. The abdomen was opened carefully and the small intestine was dissected from the mesentery. The duodenal segment in the small intestine was indicated by a loop encircling the pancreas; the position of the Meckel's diverticulum was indicated as the boundary point of the intestine; and the ileum was defined as the part extending from the Meckel's diverticulum to a point proximal to the ileocecal junction. The remaining part of the intestine was considered as jejunum. Samples of the duodenum, jejunum, and ileum were rapidly collected and fixed in buffered formaldehyde solution, and embedded in blocks of paraffin and historesin. Afterwards, the samples were semi-serially sectioned into 5 $\mu \mathrm{m}$ thickness and stained with hematoxylin-eosin and periodic acid-Schiff (PAS) reagents for the identification of goblet cells. For the morphometric study, digital images were obtained for each segment of the small intestine by using the light microscope and ImagePro-Plus software (Version 5.2, cyber average). The length of 20 whole villi and the depth of 20 crypts were measured. Selection of viable villi was performed based on the following criteria: villi base with insertion on submucosa without disruptions, interruptions, or folding of its body and an apex with simple columnar epithelium (GAVA, 2012). 
The number of goblet cells was obtained from the middle portion of 9 villi/segment of the intestine of each bird. The images were captured at $40 \mathrm{X}$ objective; the area of each region of each villus was measured in $\mathrm{mm}^{2}$, and the total number of goblet cells in this region was counted. The average number of cells was estimated per bird and was converted for a $0.1 \mathrm{~mm} 2$ villus area.

\section{Scanning electron microscopy}

Samples of ileum from the same birds were fixed in $2.5 \%$ glutaraldehyde buffered with $0.1 \mathrm{M}$ phosphate ( $\mathrm{pH}$ 7.4). All the tissues were washed in a buffer solution and fixed in $1 \%$ osmium tetroxide for 1 hour, after which they were immersed in $1 \%$ tannic acid for 1 hour and dehydrated in an increasing series of ethanol. After obtaining the critical point of drying by using carbon dioxide $\left(\mathrm{CO}_{2}\right)$, the fragments were coated with gold ions and photographed using an electronic scanning microscope (Jeol JSM-6100 model).

\section{Statistical methods}

The data were analyzed using a two-way analysis of variance (ANOVA), with challenge and diet as the main effects, and utilizing the GLM procedure of the SAS program (SAS INSTITUTE, 2002). When the interactions were significant, differences among means were separated by Tukey's multiple comparison test using the treatment means. Differences were considered statistically different at $\mathrm{P}<0.05$.

\section{Results and Discussion}

There was no significant interaction $(\mathrm{P}>0.05)$ for any variable analyzed (Table 2, 3, and 4), and thus, only the main effects means are presented. At 28 days of age, the diet with Gln/Glu $+0.80 \%$ Thr resulted in lower crypt depth of the duodenum. As a result, the villus:crypt ratio was higher in this treatment group. Broilers challenged with Eimeria sp. presented lower $(\mathrm{P}<0.05)$ number of goblet cells and higher $(\mathrm{P}<0.05)$ crypt depth, and lower villus:crypt ratio than that of control group (Table 2).

Table 2. Density of goblet cells (cells $/ 100.000 \mu \mathrm{m}^{2}$ ) and morphometry (villus length, crypt depth, and villus: crypt ratio) of duodenum of broilers at 28 and 42 days of age supplemented with glutamine and threonine, and challenged or not challenged with coccidial vaccine.

\begin{tabular}{lcccccccc}
\hline \multicolumn{1}{c}{ Diet } & Goblet cells & Villus, $\mu \mathrm{m}$ & Crypt, $\mu \mathrm{m}$ & $\mathrm{V}: \mathrm{C}$ & Goblet cells & Villus, $\mu \mathrm{m}$ & Crypt, $\mu \mathrm{m}$ & $\mathrm{V}: \mathrm{C}$ \\
\hline \multicolumn{7}{c}{28 days } \\
\hline Diet & & & & \multicolumn{5}{c}{42 days } \\
Basal Diet & 11.10 & 1017.72 & $123.14^{\mathrm{ab}}$ & $8.33^{\mathrm{ab}}$ & 8.94 & 1269.95 & 149.78 & 8.71 \\
Gln/Glu & 11.17 & 952.45 & $145.90^{\mathrm{a}}$ & $6.93^{\mathrm{b}}$ & 9.71 & 1134.58 & 173.47 & 6.69 \\
Gln/Glu +0.80\% Thr & 10.57 & 1074.92 & $104.56^{\mathrm{b}}$ & $10.55^{\mathrm{a}}$ & 8.65 & 1287.52 & 164.94 & 8.01 \\
Gln/Glu +0.85\% Thr & 11.43 & 1045.51 & $126.91^{\mathrm{ab}}$ & $8.89^{\mathrm{ab}}$ & 9.03 & 1288.80 & 180.91 & 7.00 \\
Challenge & & & & & & & & \\
Control & $11.97^{\mathrm{a}}$ & 980.13 & $98.07^{\mathrm{b}}$ & $10.30^{\mathrm{a}}$ & 10.37 & 1323.64 & 157.24 & $8.60^{\mathrm{a}}$ \\
Challenged & $10.23^{\mathrm{b}}$ & 1079.47 & $147.54^{\mathrm{a}}$ & $7.61^{\mathrm{b}}$ & 12.31 & 1175.06 & 173.38 & $6.84^{\mathrm{b}}$ \\
\hline Variance Analysis & & & & & & & & \\
\hline Diet & 0.8862 & 0.2510 & 0.0157 & 0.0230 & 0.6469 & 0.5593 & 0.8656 & 0.4191 \\
Challenge & 0.0352 & 0.1048 & 0.0001 & 0.0047 & 0.4633 & 0.1125 & 0.2150 & 0.0310 \\
Interaction & 0.8861 & 0.1348 & 0.5599 & 0.1999 & 0.1782 & 0.5005 & 0.1020 & 0.0976 \\
CV, \% & 23.45 & 21.56 & 23.94 & 20.64 & 19.68 & 21.56 & 23.94 & 23.74 \\
\hline
\end{tabular}

$\mathrm{CV}$ : coefficient of variation. Different lowercase letters in the same column differ significantly $(\mathrm{P}<0.05)$. 
At 28 days, there was no significant effect of the diet in the jejunum. The challenged broiler group presented lower $(\mathrm{P}<0.05)$ number of goblet cells and higher $(\mathrm{P}<0.05)$ crypt depth in comparison to control broilers (Table 3 ).

The crypt can be regarded as the villus factory and a large crypt indicates a rapid tissue turnover and a high demand for new tissue. The demand for energy and protein for gut maintenance is high compared to other organs. A shorter villus and a deeper crypt upon increase in the counts of pathogenic bacteria in the GIT result in fewer absorptive and more secretory cells, such as the goblet cells (MILES et al., 2006).

The proportion of goblet cells among the epithelial cell types increases caudally from the duodenum (4\%) to the distal colon (16\%), similar to the increasing number of microorganisms from the proximal intestine to the colon (CORZO et al., 2007). There are fewer and smaller goblet cells in the intestine of the germ-free animals compared to those of conventionally raised, indicating microbial modulation of goblet cells.

Table 3. Density of goblet cells (cells $/ 100.000 \mu \mathrm{m}^{2}$ ) and morphometry (villus length, crypt depth, and villus: crypt ratio) of jejunum of broilers at 28 and 42 days of age supplemented with glutamine and threonine, and challenged or not challenged with coccidial vaccine.

\begin{tabular}{lcccccccc}
\hline \multicolumn{1}{c}{ Diet } & Goblet cells & Villus, $\mu \mathrm{m}$ & Crypt, $\mu \mathrm{m}$ & $\mathrm{V}: \mathrm{C}$ & Goblet cells & Villus, $\mu \mathrm{m}$ & Crypt, $\mu \mathrm{m}$ & $\mathrm{V}: \mathrm{C}$ \\
\hline \multicolumn{7}{c}{28 days } \\
\hline Diet & & & & \multicolumn{7}{c}{42 days } \\
Basal Diet & 31.35 & 537.28 & 73.43 & 7.32 & 11.75 & 594.70 & 118.42 & 5.04 \\
Gln/Glu & 26.54 & 582.38 & 86.89 & 6.76 & 12.01 & 622.43 & 147.21 & 4.25 \\
Gln/Glu +0.80\% Thr & 25.36 & 550.74 & 79.82 & 7.00 & 9.68 & 636.35 & 125.29 & 5.06 \\
Gln/Glu +0.85\% Thr & 23.47 & 484.91 & 74.71 & 6.80 & 12.10 & 613.22 & 140.20 & 4.41 \\
Challenge & & & & & & & & \\
Control & $28.34^{\mathrm{a}}$ & 529.72 & $69.38^{\mathrm{b}}$ & 7.70 & $9.19^{\mathrm{a}}$ & 634.62 & 140.68 & 4.55 \\
Challenged & $25.16^{\mathrm{b}}$ & 541.96 & $83.50^{\mathrm{a}}$ & 6.56 & $8.84^{\mathrm{b}}$ & 584.98 & 125.36 & 4.34 \\
\hline Variance Analysis & & & & & & & & \\
\hline Diet & 0.7739 & 0.7295 & 0.5465 & 0.5143 & 0.3595 & 0.6515 & 0.3280 & 0.1791 \\
Challenge & 0.0400 & 0.4066 & 0.0222 & 0.3764 & 0.0412 & 0.1102 & 0.0576 & 0.8881 \\
Interaction & 0.6550 & 0.3938 & 0.3731 & 0.7479 & 0.3992 & 0.7633 & 0.8471 & 0.4284 \\
CV, \% & 21.71 & 26.02 & 17.66 & 25.35 & 22.50 & 18.94 & 13.80 & 17.38 \\
\hline
\end{tabular}

$\mathrm{CV}$ : coefficient of variation. Different lowercase letters in the same column differ significantly $(\mathrm{P}<0.05)$.

In case of ileum, there was a significant effect (P $>0.05$ ) of the diet on the ileal villus length (Table 4). Broilers that were fed with Gln/Glu in the diets presented more developed villi than that of broilers that received control diet $(\mathrm{P}=0.0920)$. L-glutamate is extensively oxidized in the epithelial cells of the small intestine during its transcellular journey from the lumen to the bloodstream, after its uptake from the bloodstream. This oxidative capacity coincides with the high-energy demand of the epithelium, which is always rapidly renewing and is responsible for the nutrient absorption process (RAO; SAMAK, 2012; TAPIERO et al., 2002). 
Table 4. Density of goblet cells (cells $/ 100.000 \mu \mathrm{m}^{2}$ ) and morphometry (villus length, crypt depth, and villus: crypt ratio) of ileum of broilers at 28 and 42 days of age supplemented with glutamine and threonine, and challenged or not challenged with coccidial vaccine.

\begin{tabular}{lcccccccc}
\hline Diet & Goblet cells & Villus, $\mu \mathrm{m}$ & Crypt, $\mu \mathrm{m}$ & $\mathrm{V}: \mathrm{C}$ & Goblet cells & Villus, $\mu \mathrm{m}$ & Crypt, $\mu \mathrm{m}$ & V:C \\
\hline \multicolumn{7}{c}{28 days } \\
\hline Diet & & & & \multicolumn{7}{c}{42 days } \\
Basal Diet & 23.77 & $335.93^{\mathrm{b}}$ & 69.06 & 4.97 & 17.05 & 493.17 & $102.22^{\mathrm{a}}$ & 8.94 \\
Gln/Glu & 20.84 & $414.48^{\mathrm{a}}$ & 67.73 & 6.19 & 15.80 & 479.61 & $104.41^{\mathrm{a}}$ & 9.71 \\
Gln/Glu +0.80\% Thr & 29.36 & $424.05^{\mathrm{a}}$ & 73.18 & 5.18 & 15.38 & 480.41 & $101.84^{\mathrm{a}}$ & 8.65 \\
Gln/Glu +0.85\% Thr & 24.53 & $422.47^{\mathrm{a}}$ & 73.88 & 5.75 & 15.65 & 472.97 & $83.89^{\mathrm{b}}$ & 9.03 \\
Challenge & & & & & & & & \\
Control & 24.22 & 385.59 & 65.27 & 5.98 & 15.85 & 474.5 & 97.76 & 4.62 \\
Challenged & 23.92 & 396.32 & 74.54 & 5.14 & 15.94 & 488.04 & 96.8 & 5.23 \\
\hline Variance Analysis & & & & & & & & \\
\hline Diet & 0.4031 & 0.0336 & 0.5667 & 0.0920 & 0.7042 & 0.4185 & 0.0249 & 0.2653 \\
Challenge & 0.7689 & 0.7941 & 0.1505 & 0.0771 & 0.9097 & 0.2061 & 0.6689 & 0.3677 \\
Interaction & 0.1020 & 0.7280 & 0.8174 & 0.6261 & 0.8389 & 0.0139 & 0.3931 & 0.2979 \\
CV, \% & 30.20 & 15.38 & 18.78 & 16.30 & 18.72 & 14.01 & 18.18 & 20.76 \\
\hline
\end{tabular}

$\mathrm{CV}$ : coefficient of variation. Different lowercase letters in the same column differ significantly $(\mathrm{P}<0.05)$.

The walls of the intestine thicken due to an increase in the number of inflammatory cells of the lamina propria. These villi renew their surface layer frequently, which results in shedding of almost $20 \%$ of the surface proteins daily into the lumen of the intestine (MILES et al., 2006). This justifies the longer crypt depth of the mucosa that was observed in the Eimeria challenged broiler group, thereby indicating an increased mitotic rate to compensate the cell extrusion of the villi because of the aggression to the morphological structure of the intestinal mucosa caused by the intracellular replication of Eimeria sp. Tan et al. (2014) described that the morphological alteration of the villi in this case was because of the two life cycle phases of Eimeria sp. that occurred within the intestinal epithelial cells. This resulted in the disruption and reduction in the length and width of the cells, which affected the nutrient absorption that is dependent on the ideal amount and functional integrity of intestinal cells.
Azzam et al. (2012) supplemented the diets of laying hens with L-Thr at 0.66 or $0.74 \%$, and did not find any effect on the number of goblet cells, villus length, and mucosal thickness. However, they found that the expression of MUC2 mRNA in the jejunum and ileum increased linearly with increased Thr in the diet.

No significant dietary effect $(\mathrm{P}<0.05)$ was observed for the histomorphometric parameters (Tables 2 and 3 ) in the duodenum or jejunum of the broilers at 42 days of age. Supplementation of Gln/ $\mathrm{Glu}+0.85 \% \mathrm{Thr}$ induced lower crypt depths in the ileum (Table 4). There was a significant interaction $(\mathrm{P}<0.05)$ between diet and experimental challenge on the villus length of the ileum. In the unfolding of the interaction (Table 5), supplementation of $0.80 \%$ Thr resulted in higher $(\mathrm{P}<0.05)$ villus length than with $0.85 \% \mathrm{Thr}$ in the control group. On the other hand, the diet with Gln/Glu $+0.85 \%$ Thr showed higher $(\mathrm{P}<0.05)$ villus length in comparison to control in the challenged broilers. 
Table 5. Unfolding of the interaction between diet and challenge regarding the length of the villi of the ileum mucosa of broilers at 42 days of age supplemented with glutamine and threonine, and challenged or not challenged with coccidial vaccine.

\begin{tabular}{lccc}
\hline & Control & Challenged & P value \\
\cline { 2 - 4 } Control Diet & $462.02^{\mathrm{aA}}$ & $471.86^{\mathrm{aA}}$ & 0.5379 \\
Gln/Glu & $487.96^{\mathrm{aA}}$ & $471.26^{\mathrm{aA}}$ & 0.8039 \\
Gln/Glu + 0.80 Thr & $516.92^{\mathrm{aA}}$ & $449.12^{\mathrm{bB}}$ & 0.0296 \\
Gln/Glu + 0.85 Thr & $415.88^{\mathrm{aB}}$ & $505.60^{\mathrm{aA}}$ & 0.0209 \\
P value & 0.3009 & 0.0150 & \\
\hline
\end{tabular}

Different lowercase letters in the same column and different capital letters in the same line differ significantly $(\mathrm{P}<0.05)$.

Zaghari etal.(2011) verified that supplementation with Thr influenced villus height, epithelium thickness, number of goblet cells, and crypt depth, although increased levels of $\operatorname{Thr}(0.47,0.66$, and $0.74 \%$ ) in the diet of laying hens have no effect on the number of goblet cells, villus height, or mucosal thickness (AZZAM et al., 2012).

Bartell and Batal (2007) reported that inclusion of $1 \%$ Gln increased the intestinal villi segments of the duodenum and jejunum compared to the control group in broilers up to 21 days of age. However, at 28 days of age, a positive effect of the replacement of $3 \%$ of crude protein in the diet with Gln/Glu and an increase in the Thr levels was only observed in the present experiment in case of ileal villus lengths.

Sakamoto et al. (2014) evaluated the effect of supplementation of Gln on the ileal intestinal morphometry in broilers at 21 and 42 days of age and observed greater villus heights in the Eimeria sp.-challenged groups. These studies reflected the trophic characteristic of Gln in the intestinal villus (TAPIERO et al., 2002; WU et al., 1996), as it serves as an energy source for fast and proliferative cells (DIGNASS, 2001; RAO; SAMAK, 2012; SMITH, 1990), and helps with integrity maintenance (RHOADS et al., 1997), thereby interfering with morphometry consequently.

The mechanism by which Gln stimulates the maturation and proliferation of intestinal cells in mammals is not well understood to date. Rhoads et al. (1997) suggested that membrane stimuli alter the enterocytes via sodium/hydrogen ion channels and increased ornithine-decarboxylase enzyme, and events that are associated with the oxidation of Gln and the proliferation of intestinal cells through polyamine production, which acts on the maturation and regeneration of the intestinal mucosa (WANG et al., 2007). Despite the fact that there was no effect of Thr on the number of goblet cells, it was observed that broilers, which were supplemented with Gln and Thr, showed lower crypt depths, thereby indicating that these amino acids contributed to lower cell turnover in the intestinal mucosa and consequently required lower energy losses for cell renewal, independent of the enteric challenge.

Zaghari et al. (2011) observed that the number of goblet cells in broilers up to 21 days of age decreased with increased Thr levels in the diet. Simultaneously, villi height and the length of the small intestine increased; hence, it was not clear whether the lower number of goblet cells in conditions without pathogen challenge could be associated with a greater conservation of energy for growth and production.

The absence of significant differences in the number of goblet cells in the villi did not necessarily indicate that $\mathrm{Thr}$ was not required for mucin production. Conditions and agents that affect the differentiation of precursor cells to mature goblet cells, and agents or conditions that interrupt the processes of glycosylation and protein synthesis (SMIRNOV et al., 2004) affect the biosynthesis 
of mucin. Several factors such as the inclusion of fiber in the diet (TANABE et al., 2005), Thr intake (ZAGHARI et al., 2011), fasting (THOMPSON; APPLEGATE, 2006), microbial colonization (FORDER et al., 2007), hormones (neuropeptides), and inflammatory mediators such as cytokines and lipids can affect the goblet cell activity and the production, secretion, and composition of mucin (DHARMANI et al., 2008).

In the morphological analysis of ileal villi by light and scanning electron microscopy (figures 1,2,3), the mucosa clearly changed in terms of morphology among the treatments. In the control group and in broilers provided with diets supplemented with
$\mathrm{Gln} / \mathrm{Glu}+0.70 \% \mathrm{Thr}$, the ileal mucosa exhibited a reduced thickness of villi extremities and the end of the ileal villi were thinner, particularly in the treatments that were challenged with Eimeria sp. (Figures 1 and 3).

The increased supplementation of $\mathrm{Thr}$ apparently had a positive effect on the ileal mucosa. Qualitatively, Gln/Glu $+0.80 \%$ Thr and Gln/ Glu $+0.85 \%$ Thr treatments showed villi with more rounded tips and consequently, more cells for the absorption process. In the treatments that were challenged with Eimeria sp., the villi were preserved, showed no changes, and had a rounded form (Figures2-3).

Figure 1. Light and scanning electron microscopy of ileum mucosa of the broilers at 28 days of age. Notice the destroyed aspect of villi tip (vi) in the broilers fed on control diet (A) and on Gln/Glu $+0.70 \%$ Thr infected with Eimeria sp. (Bi). Eimeria sp. infection (Ai and Bi). The degenerative aspect of villi is observed in $\mathrm{Ai}$ and $\mathrm{Bi}$, where epithelial cells are detached (arrows). Crypt (cry), Histological sections: historesin, HE, scale bar $30 \mu \mathrm{m}$; SEM scale bars: A) $200 \mu \mathrm{m}$; Ai) $150 \mu \mathrm{m}$; Bi) $100 \mu \mathrm{m}$.
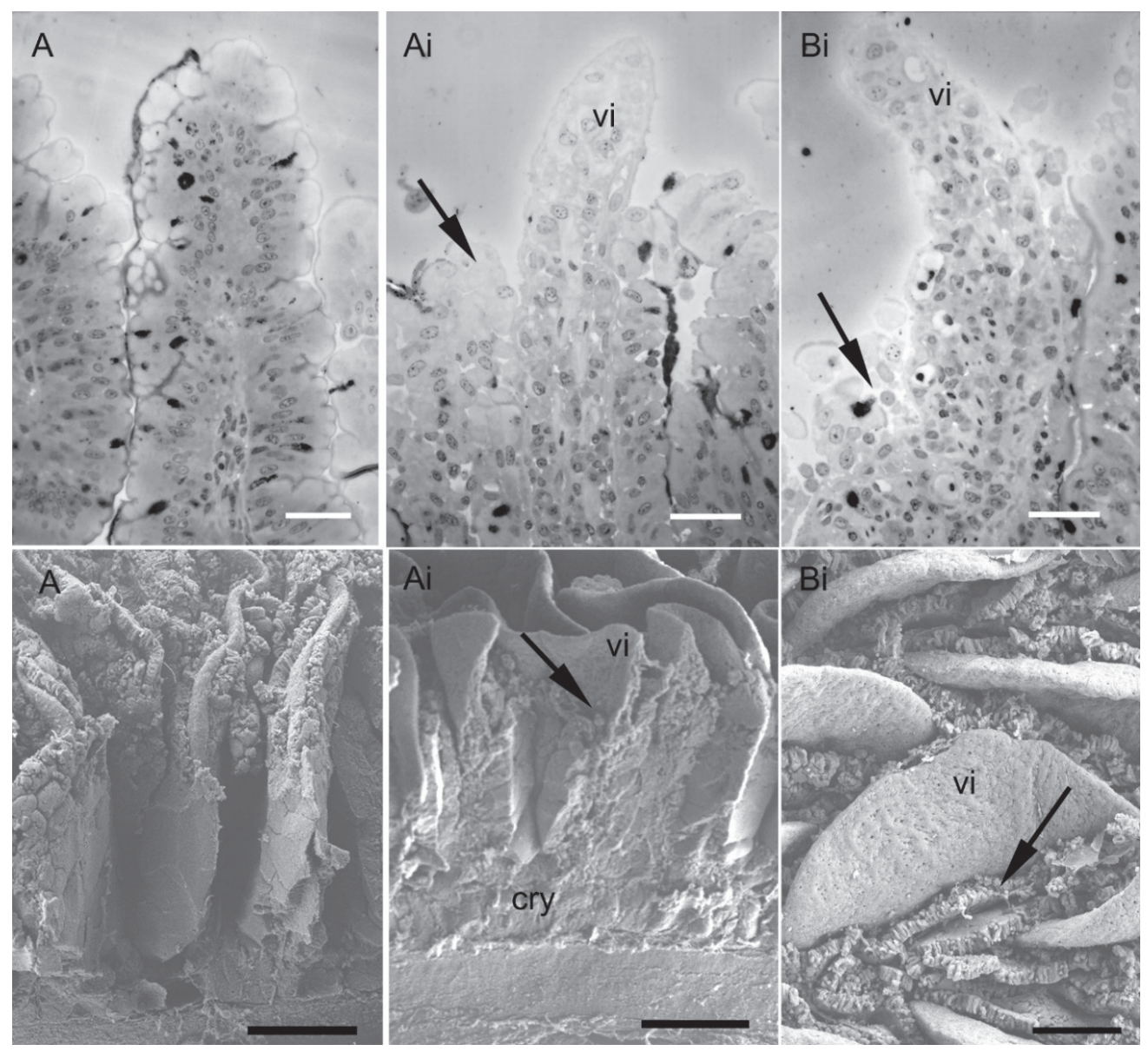

Semina: Ciências Agrárias, Londrina, v. 39, n. 3, p. 1239-1254, maio/jun. 2018 
In control and in the $\mathrm{Gln} / \mathrm{Glu}+0.70 \% \mathrm{Thr}$ treatment, both challenged with Eimeria sp, the cellular morphology was affected and the villus surface epithelium were impaired and loosing cells, thus reducing the capacity for absorption and protection of the mucosa (Figures 1, 3). Eimeria sp. infections impair the digestive and absorptive functions of the small intestine. Qualitatively, inclusion of $0.70 \%$ Thr was not enough to maintain the intestinal morphology of villus tips in the treatments that were challenged with Eimeria sp. Thr in diets had a positive effect and helped to maintain the integrity of ileal villi. These morphological results suggest a beneficial effect on the intestine health of broilers that were supplemented with Thr in combination with $\mathrm{Gln} / \mathrm{Glu}$.

These improvements, in addition to enhancing greater nutrient assimilation by the villus brush border, leads a decrease in the cellular turnover by reducing the energy expenditure required for the maintenance of broilers and consequently, can result in better performance.

Figure 2. Morphological aspect of the ileal villi (vi) upon treatments with increments of threonine (Thr): Gln/Glu + $0.80 \% \mathrm{Thr}(\mathrm{C}$ and $\mathrm{Ci}$ ) and Gln/Glu $+0.85 \% \mathrm{Thr}(\mathrm{D}$ and $\mathrm{Di}$ ) in the broilers at 28 days of age. The mucosa maintained the morphology even after Eimeria sp. infection ( $\mathrm{Ci}$ and $\mathrm{Di}$ ). The extremities of goblet cells (arrows) are visible and the enterocyte (*). Histological sections: historesin, HE, scale bar $30 \mu \mathrm{m}$; SEM scale bars: Ci) $50 \mu \mathrm{m}$; D $100 \mu \mathrm{m}$; Di) $20 \mu \mathrm{m}$.

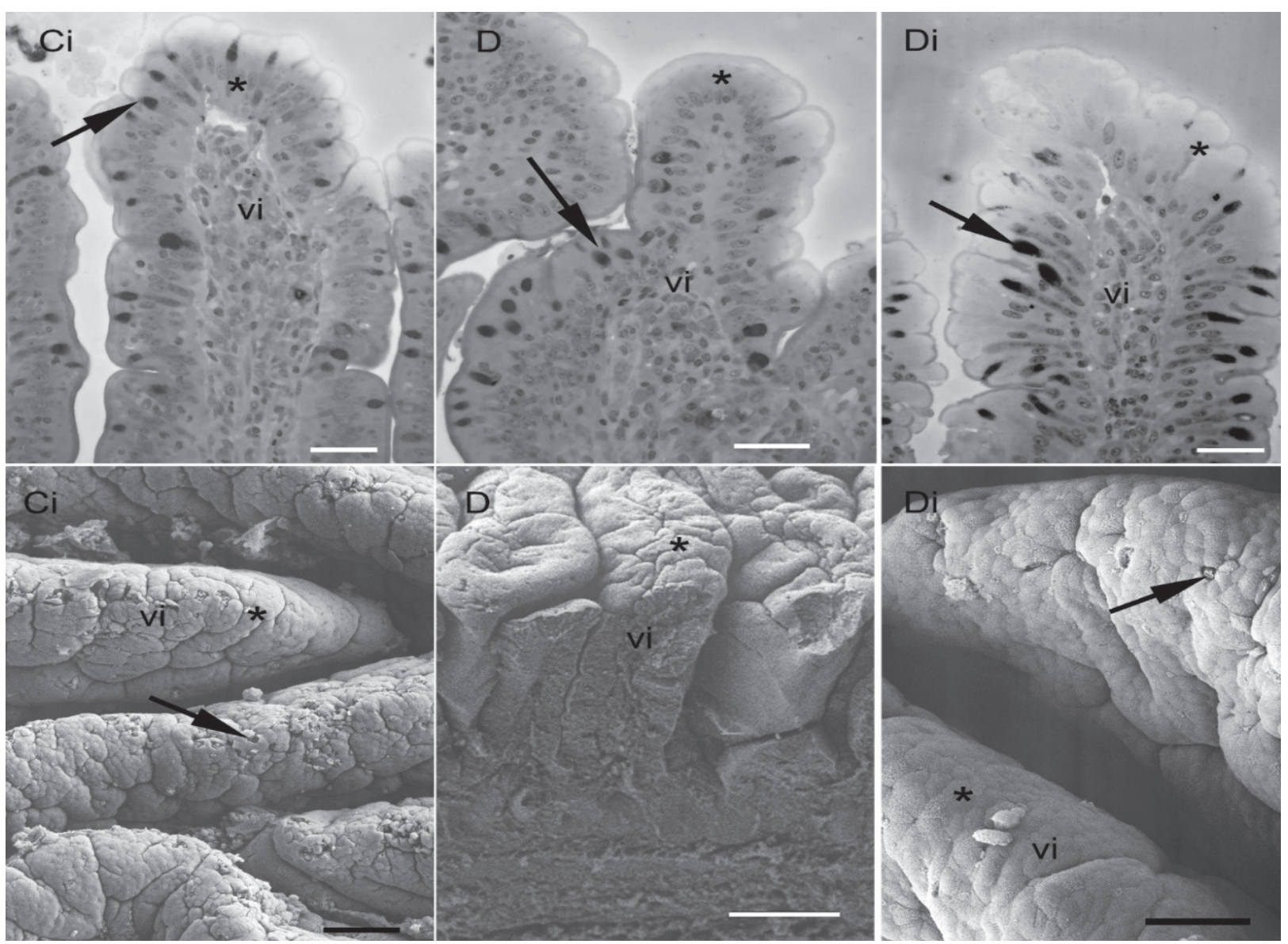


Figure 3. Scanning electron microscopic (SEM) image of the tip of the ileum villi (vi) of broilers at 42 days of age. The morphology of villi changed after glutamine and threonine treatments/supplement level. Birds treated with Eimeria sp. Bi, Ci, Di compared to non-treated birds using the same diet. Notice the loss of epithelium in $\mathrm{Ai}$ and $\mathrm{Bi}$, whereas the epithelial lining remains intact in $\mathrm{Ci}$ and $\mathrm{Di}$. $\mathrm{A}=$ control diet; $\mathrm{B}=\mathrm{Gln} / \mathrm{Glu}+0.70 \% \mathrm{Thr} ; \mathrm{C}=\mathrm{Gln} / \mathrm{Glu}+$ $0.80 \% \mathrm{Thr} ; \mathrm{D}=\mathrm{Gln} / \mathrm{Glu}+0.85 \% \mathrm{Thr}$. Scale bar: $200 \mu \mathrm{m}$.
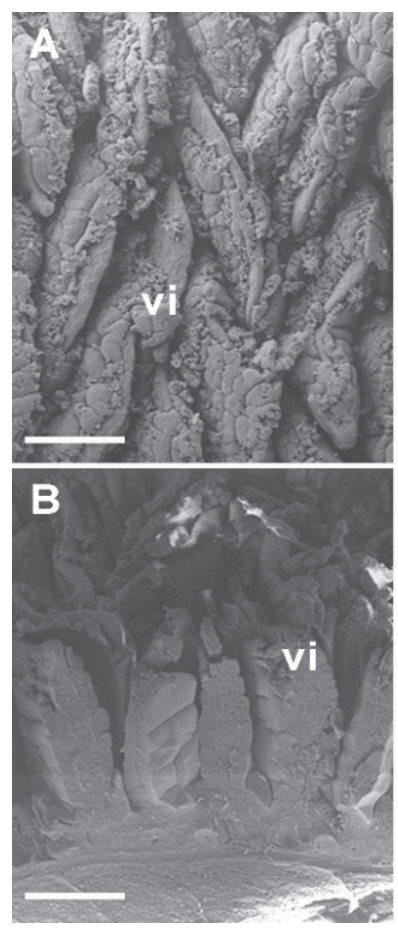
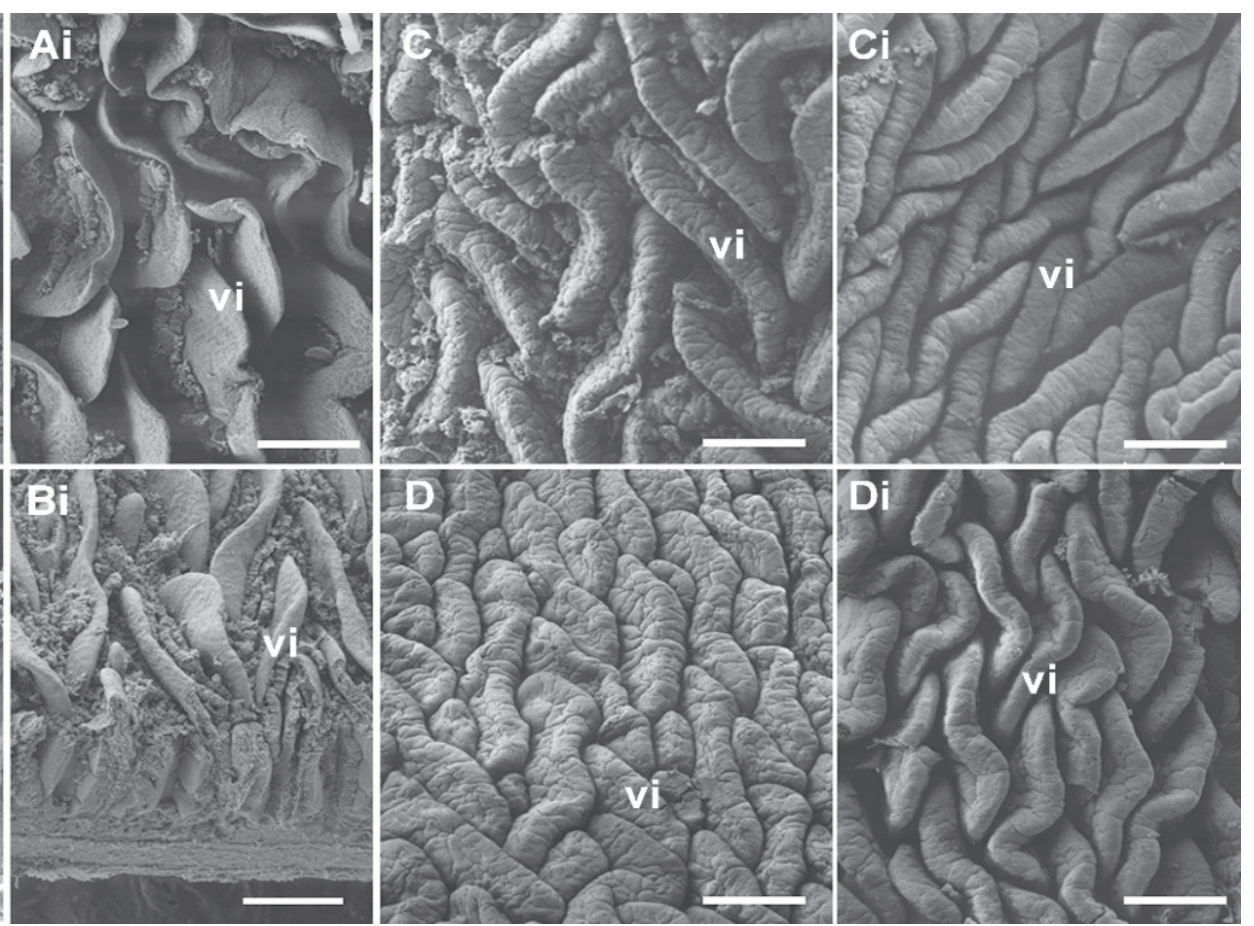

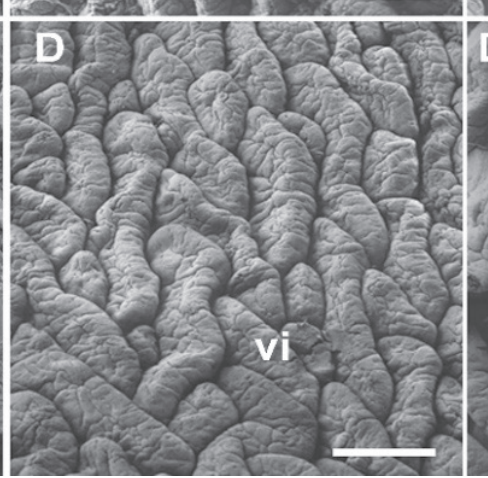

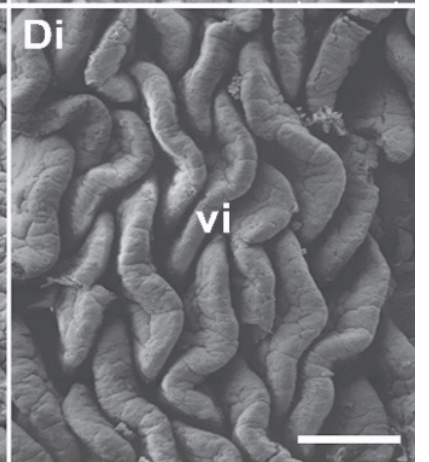

The mucosal integrity can also prevent the invasion of opportunistic agents such as $C$. perfringens, which produces a potent toxin mainly in situations that increase the susceptibility of the intestine to infectious agents, as in the case of birds challenged with Eimeria sp. (TAN et al., 2014).

The presence of mucus was remarkable in the challenged group and possibly in $\mathrm{Gln} / \mathrm{Glu}+0.70 \%$ Thr group, as it assisted in the cellular reconstitution process in the areas that were affected, after the elimination of the infectious agent. This increase in the use of Thr as a function of its large concentration in endogenous intestinal secretions (FERNANDEZ et al., 1994) can detour Thr from depositing in the meat in cases of challenge, thereby hurting the performance of broilers (OLIVEIRA; OLIVEIRA, 2009). Moreover, the combination of a higher demand for Thr to produce mucus and a lower supply because of the reduction in feed intake will lead to a shortage of Thr.

As a physical-chemical barrier to avoid the direct contact between microbiota and epithelial cells, mucus controls the microflora colonization by at least two different routes. The mucus provides colonization sites and nourishes commensal and mucolytic microorganisms via carbohydrates that are present in mucin. Moreover, mucus gel retains invading bacteria, inhibits their proliferation through interactions with other antimicrobial molecules, and eventually gets them expelled along with the luminal flow (ABBAS et al., 2011; MCGUCKIN et al., 2011).

Contradictory results are found in the literature regarding the ideal $\mathrm{Thr}$ requirement for broilers up to 42 days of age. Kidd and Kerr (1996) define the inclusion of $0.75 \% \mathrm{Thr}$ in the diet as the ideal value 
for better yields, while Dozier et al. (2000) reported that the level of $0.62 \%$ should be the maximum inclusion. Forder et al. (2007) suggested that the optimum level of supplementation of Thr for the performance and intestine functionality is between 0.65 and $0.90 \%$ for broilers at 21 days of age. Lima Neto et al. (2012) observed better intestinal development and better performance during the initial phase in broilers that received $0.68 \%$ digestible $\mathrm{Thr}$ in the diet. It is important to consider that in these studies, the birds were not challenged by any kind of microorganisms. Moreover, when the aim is to repair intestinal mucosa, the level of $\mathrm{Thr}$ that is required by broilers can be greater.

In this context, investigations of the mechanisms that stimulate the development and recovery of mucosa to improve nutrient utilization is of considerable importance for the final performance of broilers that are exposed to coccidiosis. Furthermore, considering the fact that the feed costs represent 70 to $80 \%$ of the poultry production, the integrity of the epithelial cells of the mucosa ensured that good performance and production was dependent on the feed and feed supplements.

\section{Conclusion}

Reduction of crude protein and optimization the inclusion of glutamine in diet improve the intestinal morphology of birds challenged by coccidiosis. Supplementation of glutamine and threonine positively affected the ileal villi lengths at 28 days of age. The optimum level of supplementation of threonine for the performance and intestine functionality was $0.85 \%$ for $21-42$ day-old broilers challenged by coccidiosis.

\section{Acknowledgements}

We are also grateful to Ajinomoto (São Paulo, Brazil) for providing AminoGut ${ }^{\circledR}$ and L-Threonine.

\section{References}

ABBAS, R. Z.; MUNAWAR, S. H.; MANZOOR, Z.; IQBA, Z.; KHAN, M. N.; SALEEMI, M. K.; ZIA, M. A.; YOUSAF, A. Anticoccidial effects of acetic acid on performance and pathogenic parameters in broiler chickens challenged with Eimeriatenella. Pesquisa Veterinária Brasileira, Seropédica, v. 31, n. 2, p. 99-103, 2011.

AZZAM, M. M. M.; DONG, X. Y.; XIE, P.; ZOU, X. T. Influence of L-threonine supplementation on goblet cell numbers, histological structure and antioxidant enzyme activities of laying hens reared in a hot and humid climate. Poultry Science, Savoy, v. 53, n. 5, p. 640-645, 2012.

BARTELL, S. M.; BATAL, A. B. The effect of supplemental glutamine on growth performance, development of the gastro intestinal tract, and humoral immune response of broilers. Poultry Science, Savoy, v. 86, n. 9, p. 1940-1947, 2007.

CORZO, A.; KIDD, M. T.; DOZIER, W. A.; PHARR, G. T.; KOUTSOS, E. A. Dietary threonine needs for growth and immunity of broilers raised under different litter conditions. Journal of Applied Poultry Research, Oxford, v. 16, n. 4, p. 574-582, 2007.

DHARMANI, P.; SRIVASTAVA, V.; KISSOON-SINGH, V.; CHADEE, K. Role of intestinal mucins in innate host defense mechanisms against pathogens. Journal of Innate Immunity, Basel, v. 1, n. 2, p. 123-135, 2008.

DIGNASS, A. U. Mechanisms and modulation of intestinal epithelial repair. Inflammatory Bowel Diseases, Atlanta, v. 7, n. 1, p. 68-77, 2001.

DOZIER III, W. A.; MORAN JUNIOR, E. T.; KIDD, M. T. Threonine requirement for broiler males from 42 to 56 days of age. Journal of Applied Poultry Research, Oxford, v. 9, n. 2, p. 214-222, 2000.

FASINA, Y. O.; BOWERS, J. B.; HESS, J. B.; MCKEE, S. R. Effect of dietary glutamine supplementation on Salmonella colonization in the ceca of young broiler chicks. Poultry Science, Savoy, v. 89, n. 5, p. 1042-1048, 2010.

FAURE, M.; MOENNOZ, D.; MONTIGON, F.; METTRAUX, C.; BREUILLE, D.; BALLÈVRE, O. Dietary threonine restriction specifically reduces intestinal mucin synthesis in rats. Journal of Nutrition, Rockville, v. 135, n. 3, p. 486-491, 2005.

FERNANDEZ, R. S.; AOYAGI, S.; HAN, Y.; PARSONS, C. M.; BAKER, D. H. Limiting order of amino acid in corn and soybean cereal for growth of the chick. Poultry Science, Savoy, v. 73, n. 12, p. 1887-1896, 1994. 
FORDER, R. E. A.; HOWARTH, G. S.; TIVEY, D. R.; HUGHES, R. J. Bacterial modulation of small intestinal goblet cells and mucin composition during early posthatch development of poultry. Poultry Science, Savoy, v. 86, n. 11, p. 2396-2403, 2007.

GAVA, M. S. Metodologia de morfometria intestinal em frangos de corte. 2012. Dissertação (Mestrado em Ciência Veterinária) - Universidade Federal do Rio Grande do Sul, Porto Alegre.

GUARNER, F. Enteric flora in health and disease. Digestion, Amsterdam, v. 73, n. 1, p. 5-12, 2006.

KIDD, M. T. Nutritional modulation of immune function in broilers. Poultry Science, Savoy, v. 83, n. 4, p. 650$657,2004$.

KIDD, M. T.; KERR, B. J. Threonine and broiler nutrition. In: MEETING ARKANSAS NUTRITION CONFERENCE, 1996, Fayetteville. Proceeding... Fayetteville: The Poultry Federation, 1996. p. 203-228.

KIDD, M. T.; KERR, B. J.; ANTHONY, N. B. Dietary interactions between lysine and threonine in broilers. Poultry Science, Savoy, v. 76, n. 4, p. 608-614, 1997.

KLASING, K. C. Nutrition and the immune system. British Poultry Science, London, v. 48, n. 5, p. 525-537, 2007.

LAW, G. K.; BERTOLO, R. F.; ADJIRI-AWERE, A. Adequate oral threonine is critical for mucin production and gut function in neonatal piglets. American Journal of Physiology - Gastrointestinal, Bethesda, v. 292, n. 5, p. 1293-1301, 2007.

LIMA NETO, R. C.; COSTA, F. G. P.; FURLAN, R. L.; GIVISIEZ, P. E. N.; GOULART, C. C.; OLIVEIRA, C. F. S.; MORAIS, S. A. N.; BEZERRA, R. M.; LIMA, M. R. Levels of digestible Threonine for male broilers from 1 to 7 days of age. Journal of Applied Poultry Research, Oxford, v. 21, n. 4, p. 757-763, 2012.

LIN, C. H.; CORREIA, L.; TOLIA, K.; GESELL, M. K.; TOLIA, V.; LEE, P. C.; LUK, G. D. Early weaning induces jejunal ornithine decarboxylase and cell proliferation in neonatal rats. Journal of Nutrition, Rockville, v. 128, n. 10, p. 36-42, 1998.

MCGUCKIN, M. A.; LIND'EN, S. K.; SUTTON, P.; FLORIN, T. H. Mucin dynamics and enteric pathogens. Nature Reviews Microbiology, Madrid, v. 9, n. 4, p. 265278, 2011.

MILES, R. D.; BUTCHER, G. D.; HENRY, P. R.; LITTELL, R. C. Effect of antibiotic growth promoters on broiler performance, intestinal growth parameters, and quantitative morphology. Poultry Science, Savoy, v. 85, n. 3, p. 476-485, 2006.
MOGHADDAM, H. S.; MOGHADDAM, H. N.; KERMANSHAHI, H.; MOSAVI, A. H.; RAJI, A. The effect of threonine on mucin 2 gene expression, intestinal histology and performance of broiler chicken. Italian Journal of Animal Science, Champaign, v. 10, n. 2, p. 66-71, 2011.

MONTAGNE, L.; PIEL, C.; LALLE'S, J. P. Effect of diet on mucin kinetics and composition: Nutrition and health implications. Nutrition Research Reviews, Belfast, v. 62, n. 3, p. 105-114, 2004.

MYRIE, S. B.; BERTOLO, R. F.; SAUER, W. C. Effect of common antinutrive factors and fibrous feed stuffs in pig diets on amino acid digestibilities with special emphasis on threonine. Journal of Animal Science, Champaign, v. 86, n. 3, p. 609-619, 2006.

NICHOLS, N. L.; BERTOLO, R. F. Luminal threonine concentration acutely affects intestinal mucosal protein and mucin synthesis in piglets. The Journal of Nutrition, Rockville, v. 138, n. 7, p. 1298-1303, 2008.

OLIVEIRA, A. R. N.; OLIVEIRA, W. P. Aminoácidos para frangos de corte. Revista Brasileira de Zootecnia, Viçosa, MG, v. 38, p. 205-208, 2009. Suplemento Especial.

RAO, R. K.; SAMAK, G. Role of glutamine in protection of intestinal epithelial tight junctions. Journal of Epithelial Biology \& Pharmacology, Saskatoon, v. 5, n. 1, p. 47-54, 2012.

RHOADS, J. M.; ARGENZIO, R. A.; CHEN, W.; RIPPE, R. A.; WESTWICK, J. K.; COX, A. D.; BERSCHNEIDER, H. M.; BRENNER, D. A. L-glutamine stimulates intestinal cell proliferation and activates mitogen activated protein kinase. American Journal of Physiology, Bethesda, v. 272, n. 5, p. 943-953, 1997.

SAKAMOTO, M. I.; FARIA, D. E.; NAKAGI, V. S.; MURAKAMI, A. E. Sources of trophic action on performance and intestinal morphometry of broiler chickens vaccinated against coccidiosis. Revista Brasileira de Ciencia Avicola, Campinas, v. 16, n. 4, p. 389-396, 2014.

SMIRNOV, A.; SKLAN, D.; UNI, Z. Mucin dynamics in the chick small intestine are altered by starvation. Journal of Nutrition, Rockville, v. 134, n. 4, p. 736-742, 2004.

SMITH, R. J. Glutamine metabolism and its physiological importance. Journal of Parenteral and Enteral Nutrition, Silver Spring, v. 14, n. 4, p. 40-44, 1990.

STAR, L.; ROVERS, M.; CORRENT, E.; VAN DER KLIS, J. D. Threonine requirement of broiler ckickens during subclinical intestinal Clostridium infection. Poultry Science, Savoy, v. 91, n. 3, p. 643-652, 2012. 
STATISTICAL ANALYSIS SYSTEM INSTITUTE SAS Institute. User's guide. Cary: SAS Institute, 2002. $525 \mathrm{p}$.

TAN, J.; APPLEGATE, T. J.; LIU, S.; GUO, Y.; EICHER, S. D. Supplemental dietery L-arginine attenuates intestinal mucosal disruption during a coccidial vaccine challenge in broiler chickens. British Journal of Nutrition, London, v. 112, n. 7, p. 1098-1109, 2014.

TANABE, H. S.; TOMISHIMA, S.; NAGAI, S.; SAKO, $Y$. Identification of a gene induced in conjugationpromoted cells of toxic marine dinoflagellates Alexandrium tamarense and Alexandrium catenella using differential display analysis. FEMS Microbiology Letters, Oxford, v. 251, n. 1, p. 161-168, 2005.

TAPIERO, H.; MATHE, G.; COUVREUR, P.; TEW, K. D. Free amino acids in human health and pathologies - II. Glutamine and glutamate. Biomedicine Pharmacotherapy, Charleston, v. 56, n. 9, p. 446-457, 2002.

THOMPSON, K. L.; APPLEGATE, T. J. Feed with draw alters small-intestinal morphology and mucus of broilers. Poultry Science, Savoy, v. 85, n. 9, p. 1535-15, 2006.
WANG, X.; QIAO, S.; YIN, Y.; YUE, L.; WANG, K.; WU, G. A deficiency or excess of dietary threonine reduces protein synthesis in jejunum and skeletal muscle of young pigs. Journal of Nutrition, Rockville, v. 137, n. 6, p. 1442-1446, 2007.

WITTIG, B.; ZEITZ, M. The gut as an organ of immunology. International Journal of Colorectal Disease, Madrid, v. 18, n. 3, p. 181-187, 2003.

WU, G.; MEIER, S. A.; KNABE, D. A. Dietary glutamine supplementation prevents jejunal atrophy in weaned pigs. Journal of Nutrition, Rockville, v. 126, n. 10, p. 2578-2584, 1996.

YEGANI, M.; KORVER, D. R. Factors affecting intestinal health in poultry. Poultry Science, Savoy, v. 87, n. 10, p. 2052-2063, 2008.

ZAGHARI, M.; ZAEFARIAN, F.; SHIVAZAD, M. Standardized ileal digestible threonine requirements and its effects on performance and gut morphology of broiler chicks fed two levels of protein. Journal of Agricultural Science and Technology, Tehran, v. 13, n. 4, p. 541-552, 2011. 
